\title{
ROLE OF MAGENISUM, WATER CONTENT AND FRETILIZERS ON SOME ELEMENTS AVAILABILITY IN CLAYEY SOIL \\ Hammad, S. A. ${ }^{1}$; T. M. El-Zehery ${ }^{1}$; Y. S. El-Arquan ${ }^{1}$ and Marwa G. El-Moogy \\ ${ }^{1}$ Soil Sci. Dept., Fac. of Agric., Mansoura Univ., Egypt. \\ ${ }^{2}$ Soils, Water \&Environment Institute., agric. Res. Centre, Giza, Egypt.
}

\begin{abstract}
A Laboratory experiment carried out during 2010/2011 at Fac. Agric., Mansoura Univ., to study some nutrients availability in clayey soil as affected by magnesium, water content and mineral fertilizers. The used experimental design was spilt-spilt design with three replicated.

- Statistical analysis of the obtained results reveal that the content of all Av. nutrients increased significantly in the upper soil section $(0-5 \mathrm{~cm})$ with $\mathrm{Mg}$ addition, $150 \%$ field capacity and fertilizer treatments

- Data reveal that the content of all Av. nutrients increased significantly in the lower soil section $(5-10 \mathrm{~cm})$ with $\mathrm{Mg}$ addition, $150 \%$ of field capacity and fertilizer treatments but the content of Av. Ammonium increased insignificantly with adding of $\mathrm{Mg}$.

- Data reveal that the increasing percent of all Av. nutrients concentration caused by magnesium and water content under different fertilizer condition. It noticed under different mineral fertilizer treatments that treatment with Mg1W2 gave the highest increasing percentage of all Av. nutrients as compared to control (MgOW1) in both section.

- Data reveal that, the fertilizer treatment F3 application raising the content of Av. K in the first section of soil column. It also shows that the best fertilizer treatments for increase the content of $\mathrm{Av} . \mathrm{NH}_{4}{ }^{+}$and $\mathrm{NO}_{3}{ }^{-}$in the first section of soil column were $\mathrm{F} 2$. Also with adding of treatment of F5, a highly increase of Av. P content in the first section of soil column high increased in both section.

-It can be concluded that the highest mean values of the content of all Av. nutrients obtained from Mg1W2 among all treatment.
\end{abstract}

\section{INTRODUCTION}

Large areas in different governorates were suffering from decreasing magnesium content. There is a continuous depletion of magnesium from Egyptian soils and adding magnesium fertilizers would help in sustaining the soil fertility, prevent its deterioration in soils and increase yields without harming the environment. El-Fouly, et al., (2010).

Magnesium (Mg) is the most abundant cation occupying the exchange sites of the soil colloids, both inorganic and organic. These found in soil solution and adsorbed on the clay and organic matter surfaces. Soils usually contain less $\mathrm{Mg}$ than $\mathrm{Ca}$ because $\mathrm{Mg}^{2+}$ ions not adsorbed, as strongly by clay and organic matter as $\mathrm{Ca}^{2+}$ ions on the other hand, $\mathrm{Mg}^{2+}$ ions are more susceptible to leaching than $\mathrm{Ca}^{2+}$ ions. Soil magnesium is a moderately leachable nutrient as compared to calcium, and greater amounts often found 
Hammad, S. A. et al.

in the subsoil than in the upper parts of the soil profile, especially in older and highly weathered soils. Senthurpandian et al., (2009).

In Egypt, chemical fertilizers used heavily to maintain to the soil fertility and to ensure crop production. Badiane, et al. (1994) reported that Egypt's consumption of fertilizers is more than 10 times as much of all nutrients per hectare as dose the average for the whole world.

Water content is one of the most variable characteristics of soil. The soil acts as a reservoir for water, making it available for plants as it needed. Soil water is very important to the entire soil system, not only because it is necessary for plant growth, but because the nutrients required for plant growth are also present in the soil solution. Most of the important soil reactions (weathering, cation exchange, organic matter decomposition, fertilization) take place in the context of the soil solution. Thus, it is evident that the moisture status of a soil is a key property.

The interaction of water with soil colloids plays a critical role in all areas of soil science, and numerous studies have shown that exchangeable cations significantly influence soil-water relations. Dontsova, et al., (2004). Therefore, the present study aimed to study some nutrients availability as affected by magnesium, water content and mineral fertilizers in clayey soil.

\section{MATERIALS AND METHODS}

An experiment carried out during 2010/2011 at the Laboratory experiment in Fac. Agric., Mansoura Univ., to study the nutrients availability in clayey soil as affected by magnesium, water content and mineral fertilizers. The used experimental design was spilt-spilt design with three replicated. The experiment conducted out in the incubation experiment using soil column using PVC cylinder with diameter $10 \mathrm{~cm}$ and length $26 \mathrm{~cm}$, the soil put and compressed in a plastic bag then put in a PVC cylinder. Soil column have $2.28 \mathrm{~kg}$ of clayey soil arranged in the plastic bags and this weight give us height of $20 \mathrm{~cm}$. Combination effect of mineral fertilizer with magnesium:

Five treatments of mineral fertilizers as following:

- Control (without mineral fertilizers) (F1).

- Nitrogen (F2).

- Nitrogen + potassium (F3).

- Nitrogen + phosphorus (F4).

- Nitrogen + potassium + phosphorus (F5)

Two treatments of magnesium fertilizers as following:

- Without magnesium (Mg0).

- With magnesium (Mg1).

The moisture adjusted at two levels:

- Rate of $100 \%$ of field capacity (W1)

The Fertilizer used:

- Rate of $150 \%$ of field capacity (W2).

N Fertilizer: Ammonium Nitrate $\mathrm{NH}_{4} \mathrm{NO}_{3}(33.5 \% \mathrm{~N})$ was used as a source of $\mathrm{N}$. Each $\mathrm{N}$ treatment, were received $0.455 \mathrm{~g} \mathrm{Ammonium} \mathrm{Nitrate} \mathrm{column}^{-1}$ 
which equal $\left(0.2 \mathrm{~g}\right.$ Ammonium Nitrate $\mathrm{kg}^{-1}$ soil, and $153 \mathrm{~kg}$ Ammonium Nitrate fed $^{-1}$ ).

P Fertilizer: Calcium super phosphate $\mathrm{Ca}\left(\mathrm{H}_{2} \mathrm{PO}_{4}\right)_{2}+\mathrm{CaSO}_{4}\left(15.5 \% \mathrm{P}_{2} \mathrm{O}_{5}\right)$ was used as a source of $P$. Each $P$ treatments received $0.343 \mathrm{~g}$ super phosphate column ${ }^{-1}$, which equal $\left(0.151 \mathrm{~g}^{-1}\right.$ super phosphate $\mathrm{kg}^{-1}$ soil, and 150 $\mathrm{kg}$ super phosphate $\mathrm{fed}^{-1}$ ).

K Fertilizer: Potassium sulfate $\mathrm{K}_{2} \mathrm{SO}_{4}\left(50 \% \mathrm{~K}_{2} \mathrm{O}\right)$ was used as a source of $\mathrm{K}$. Each $\mathrm{K}$ treatments received $0.2275 \mathrm{~g}$ potassium sulfate column ${ }^{-1}$, which equal $\left(0.1 \mathrm{~g}\right.$ potassium sulfate $\mathrm{kg}^{-1}$ soil, and $\left.100 \mathrm{~kg}_{\text {potassium sulfate fed }}{ }^{-1}\right)$.

Mg Fertilizer: Magnesium sulfate $\mathrm{MgSO}_{4} \cdot 7 \mathrm{H}_{2} \mathrm{O}$ was used as a source of $\mathrm{Mg}$. Each $\mathrm{Mg}$ treatments received $0.3731 \mathrm{~g}$ magnesium sulfate column ${ }^{-1}$, which equal $\left(0.164 \mathrm{~g}\right.$ magnesium sulfate $\mathrm{kg}^{-1}$ soil, and $80 \mathrm{~kg}$ magnesium sulfate fed $\left.^{1}\right)$.

Data in Table 1 show some physical and chemical properties of the experimental soil. Soil samples were sieved and routine analysis in the beginning of the experiment done according to Dewis and Freitas (1970), Hesse (1971) and Piper (1950). Soil samples were taken after 20 days from the beginning of the experiment. All columns separated to 2-section graduate from the top to down with a height of $5 \mathrm{~cm}$ to be analyses.

Table 1: Some physical and chemical properties of the experiment soil.

\begin{tabular}{|c|c|c|c|c|c|c|c|c|c|}
\hline \multirow{2}{*}{$\begin{array}{c}\mathrm{pH} \\
(1: 2.5)\end{array}$} & \multirow{2}{*}{$\begin{array}{l}\begin{array}{l}\text { E.C ds.m } \\
\text { (soil paste) }\end{array} \\
\text { (s) }\end{array}$} & \multicolumn{8}{|c|}{ lons $\mathrm{mg} \mathrm{kg}^{-1}$ soil } \\
\hline & & $\mathrm{Ca}^{+2}$ & $\mathrm{Mg}^{+2}$ & $\mathrm{Na}^{+}$ & $\mathrm{K}^{+}$ & $\mathrm{CO}_{3}{ }^{-2}$ & $\mathrm{HCO}_{3}{ }^{-}$ & $\mathrm{Cl}^{-}$ & $\mathrm{SO}_{4}^{-2}$ \\
\hline 8.2 & 0.27 & 0.33 & 0.63 & 0.34 & 0.07 & - & 0.2 & \begin{tabular}{|l|}
0.38 \\
\end{tabular} & 0.79 \\
\hline \multicolumn{4}{|c|}{ Mechanical analysis \% } & \multirow{2}{*}{ O.M \% } & \multirow{2}{*}{$\mathrm{CaCO}_{3} \%$} & \multicolumn{4}{|c|}{ Available (ppm) } \\
\hline sand & Silt & Clay & Texture & & & $\mathbf{N}$ & $\mathbf{P}$ & & K \\
\hline 36.58 & 29.9 & 33.52 & \begin{tabular}{|l|} 
clay loam \\
\end{tabular} & 0.5 & 1.3 & 66.15 & 15 & & 210 \\
\hline
\end{tabular}

All data statistically analyses according to the technique of analysis of variance (ANOVA) and the least significant differences between the treatment means as published by Gomez and Gomez (1984).

\section{RESULTS AND DISCUSSION}

\section{Available nutrients $\left(\mathrm{mg} \mathrm{kg}^{-1}\right)$ in the upper soil section $(0-5 \mathrm{~cm})$ :- a. Single effect}

As shown in Table (2) concerning Mg treatments, it found that with $\mathrm{Mg}$ addition the content of all $\mathrm{Av}$. nutrients increased significantly with $\mathrm{Mg}$ addition. The increasing percentages were 45.16, 30.2, 10.43, 14.71 and $18.66 \%$ as compared with control for $\mathrm{Av}$. $\mathrm{Mg}, \mathrm{K}, \mathrm{NH}_{4}{ }^{+}, \mathrm{NO}_{3}{ }^{-}$and $\mathrm{P}$ respectively.

Concerning water content treatments, it found that all Av. nutrients increased significantly with $150 \%$ of field capacity. The increasing percentages of nutrients availability were as follow $\mathrm{P}>\mathrm{K}>\mathrm{Mg}>\mathrm{NO}_{3}{ }^{-}>\mathrm{NH}_{4}{ }^{+}$.

Concerning fertilizer treatments, it found that with fertilizer treatments additions the content of all Av. nutrients in the first section of soil column increased significantly. The increasing percentages of Av. magnesium were (42.25, 50.40, 48.76 and 41.57\%), Av. potassium was (21.35, 52.25, 8.99 and 
51.13\%), Av. ammonium was (10.89, 5.72, 9.57 and 7.66\%), Av. nitrate was (25.52, 20.65, 23.70 and 21.28\%) and Av. phosphorus was 11.23, 11.50, 21.86 and $36.68 \%$ as compared with control (F1).

Table 2: Effect of $\mathrm{Mg}$, water content and fertilizer treatments on available nutrients in the upper section of the soil column (0$5 \mathrm{~cm}$ ).

\begin{tabular}{|c|c|c|c|c|c|}
\hline Treatments & K & $\mathrm{NH}_{4}$ & $\mathrm{NO}_{3}$ & $\mathbf{P}$ & $\mathbf{M g}$ \\
\hline Mg0 & $191.10 \mathrm{~b}$ & $42.94 \mathrm{~b}$ & $40.05 \mathrm{~b}$ & $26.90 \mathrm{~b}$ & $632.16 \mathrm{~b}$ \\
\hline Mg1 & $248.82 \mathrm{a}$ & $47.42 \mathrm{a}$ & $45.94 \mathrm{a}$ & $31.92 \mathrm{a}$ & $917.64 \mathrm{a}$ \\
\hline F test & ** & $\star \star$ & * & * & ** \\
\hline LSD at $5 \%$ & 3.493 & 0.047 & 3.654 & 2.275 & 1.789 \\
\hline W1 & $197.73 \mathrm{~b}$ & $44.21 \mathrm{~b}$ & $41.46 \mathrm{~b}$ & $25.78 \mathrm{~b}$ & $715.20 \mathrm{~b}$ \\
\hline W2 & $242.19 \mathrm{a}$ & $46.16 \mathrm{a}$ & $44.53 \mathrm{a}$ & $33.04 \mathrm{a}$ & $834.60 \mathrm{a}$ \\
\hline F test & ** & * & ** & ** & ** \\
\hline LSD at $5 \%$ & 6.646 & 1.537 & 1.258 & 0.448 & 0.385 \\
\hline F1 & $173.55 \mathrm{~d}$ & $42.32 \mathrm{~d}$ & $36.37 \mathrm{c}$ & $25.30 \mathrm{~d}$ & $567.30 \mathrm{e}$ \\
\hline F2 & $210.60 \mathrm{~b}$ & $46.93 \mathrm{a}$ & $45.65 \mathrm{a}$ & $28.14 \mathrm{c}$ & $807.00 \mathrm{c}$ \\
\hline F3 & $264.23 \mathrm{a}$ & $44.74 \mathrm{c}$ & $43.88 \mathrm{~b}$ & $28.21 \mathrm{c}$ & $853.20 \mathrm{a}$ \\
\hline F4 & $189.15 \mathrm{c}$ & $46.37 \mathrm{a} \mathrm{b}$ & $44.99 \mathrm{a} \mathrm{b}$ & $30.83 \mathrm{~b}$ & $843.90 \mathrm{~b}$ \\
\hline F5 & $262.28 \mathrm{a}$ & $45.56 \mathrm{bc}$ & $44.11 \mathrm{~b}$ & $34.58 \mathrm{a}$ & $803.10 \mathrm{~d}$ \\
\hline F test & ** & ** & ** & ** & ** \\
\hline LSD at $5 \%$ & 6.597 & 1.306 & 1.240 & 0.775 & 2.361 \\
\hline
\end{tabular}

\section{b.Interaction effect:-}

Data in Fig (1) show the interaction effect of magnesium, water and fertilizer in the upper soil section $(0-5 \mathrm{~cm})$ it found that increased the percentage of potassium concentration as compared to $\mathrm{F} 1$. Under MgOW1 were $(2.78,66.67,16.67$ and $63.89 \%)$ and $\mathrm{Mg} 1 \mathrm{~W} 2$ were $(33.90,44.07,5.08$ and $35.59 \%$ ) so it is noticed from these percentages that treatment with F3 gave the highest increasing percentage of potassium compared to control (F1). Under Mg1W1 were (21.43, 57.14, 9.52 and 61.90\%) and Mg0W2 were $(22.50,50,10$ and $55 \%)$. It noticed from these percentages that the treatment with F5 gave the highest increasing percentage of potassium as compared to control.

Data in Fig (2) show the interaction effect of magnesium, water and fertilizer in the upper soil section $(0-5 \mathrm{~cm})$ it found that increased phosphorus concentration percentage as compared to $\mathrm{F} 1$. These increases were MgOW1 (8.56, 12.60, 38.41 and $67.98 \%), \operatorname{MgOW} 2(11.60,6.61,12.60$ and $29.89 \%)$, Mg1W1 (3.21, 4.86, 7.66 and 23.88\%) and Mg1W2 (19.85, 21.43, 33.10 and $34.94 \%)$. It noticed from these percentages that the treatment with F5 gave the highest increasing percentage of phosphorus as compared to control.

Data in Fig (3) show the interaction effect of magnesium, water and fertilizer in the upper soil section $(0-5 \mathrm{~cm})$ it found that increased nitrate concentration percentage as compared to $\mathrm{F} 1$. These increases were $\mathrm{MgOW} 1$ (32.32, 21.49, 35.47 and $30.41 \%$ ) and MgOW2 (26.19, 20.37, 26.56 and $23.10 \%)$. It noticed from these percentages that treatment with F4 gave the highest increasing percentage of nitrate as compared to control. Under Mg1W1 (31.03, 27.93, 24.33, 27.38\%) and Mg1W2 (15.60, 14.31, 12.45 and 
$8.30 \%$ ). It noticed from these percentages that treatment with F2 gave the highest increasing percentage of nitrate as compared to control.

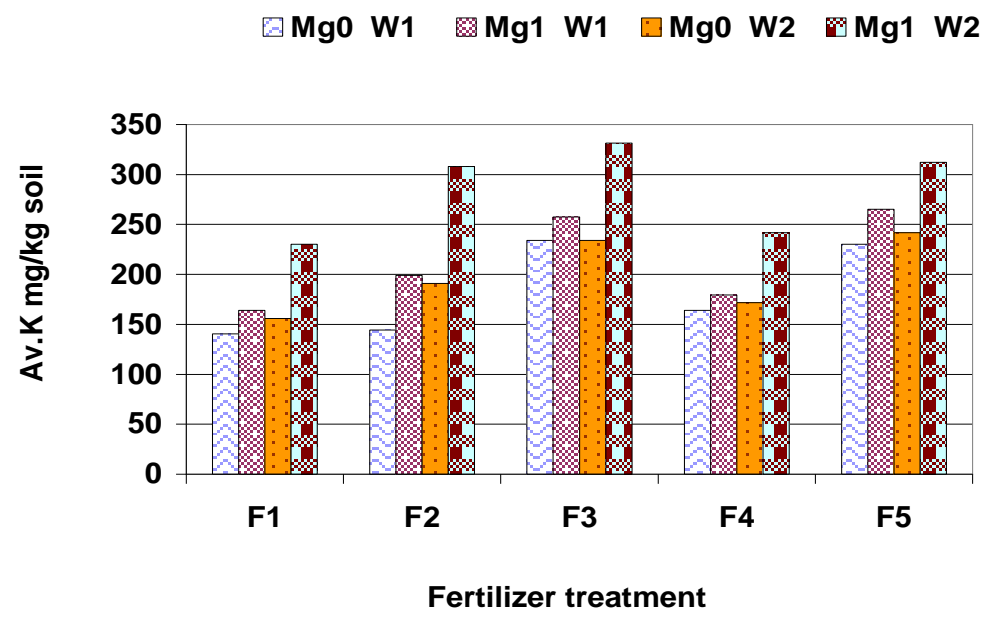

Fig (1): Effect of fertilizer treatments, $\mathrm{Mg}$, and water content on $\mathrm{Av} . \mathrm{K}$ in the upper $5 \mathrm{~cm}$ soil.

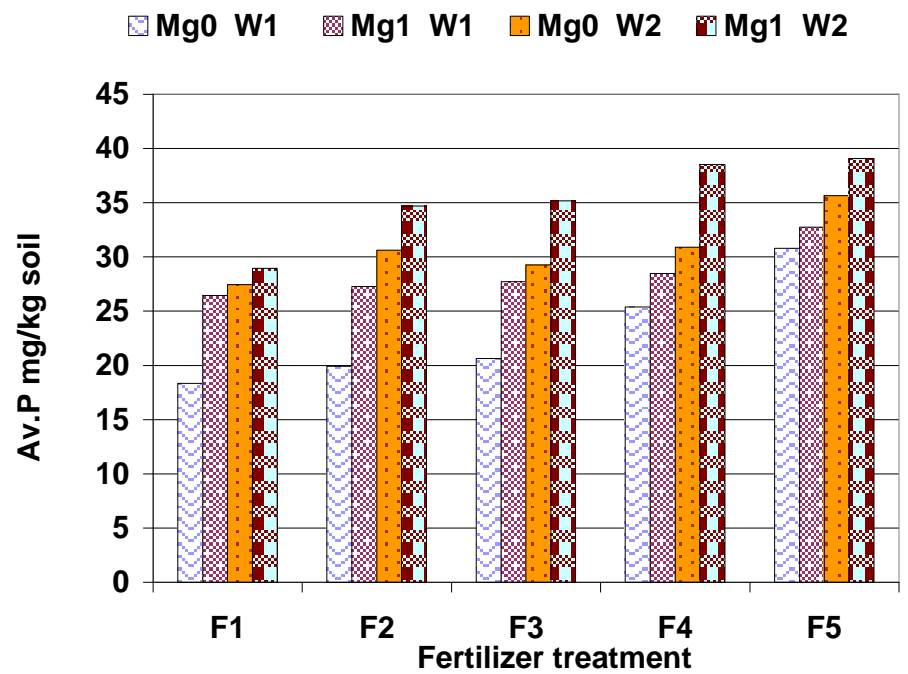

Fig (2): Effect of fertilizer treatments, $\mathrm{Mg}$, and water content on Av. P in the upper $5 \mathrm{~cm}$ soil. 
Hammad, S. A. et al.

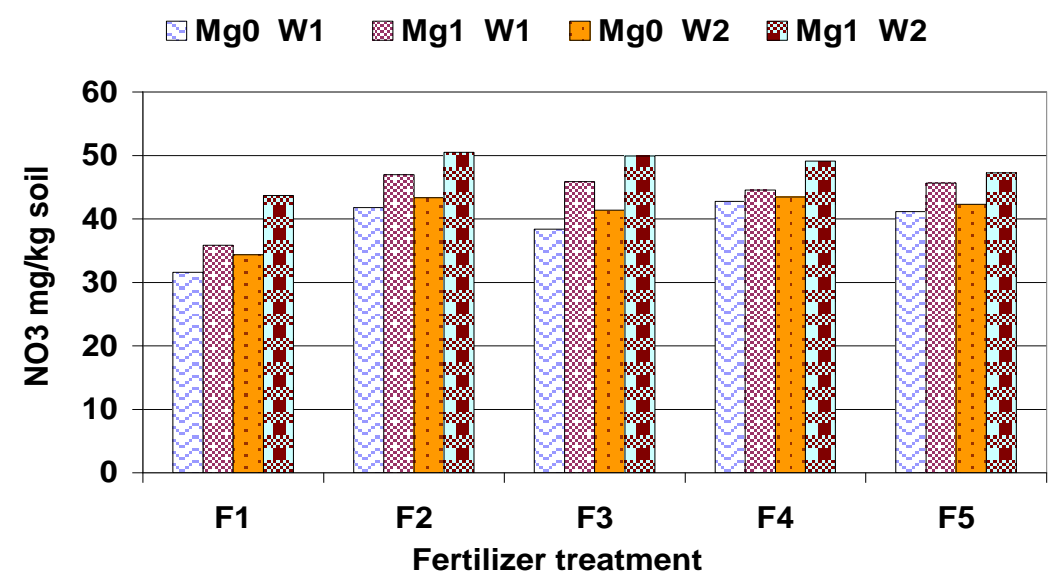

Fig (3): Effect of fertilizer treatments, $\mathrm{Mg}$, and water content on $\mathrm{NO}_{3}$ in the upper $5 \mathrm{~cm}$ soil.

Data in Fig (4) show the interaction effect of magnesium, water and fertilizer in the upper soil section $(0-5 \mathrm{~cm})$ it found that increased ammonium concentration percentage as compared to $\mathrm{F} 1$. These increases were $\mathrm{MgOW} 1$ (9.50, 4.55, 12.60 and $8.14 \%$ ) and Mg0W2 (6.46, 1.23, 8.05and 4.05\%). It noticed from these percentages that treatment with $\mathrm{F} 4$ gave the highest increasing percentage of ammonium as compared to control. Under Mg1W1 (11.88, 2.85, 6.30and 4.88\%) and Mg1W2 (15.33, 13.84, 11.48 and $13.35 \%$ ). It noticed from these percentages that treatment with F2 gave the highest increasing percentage of ammonium as compared to control.

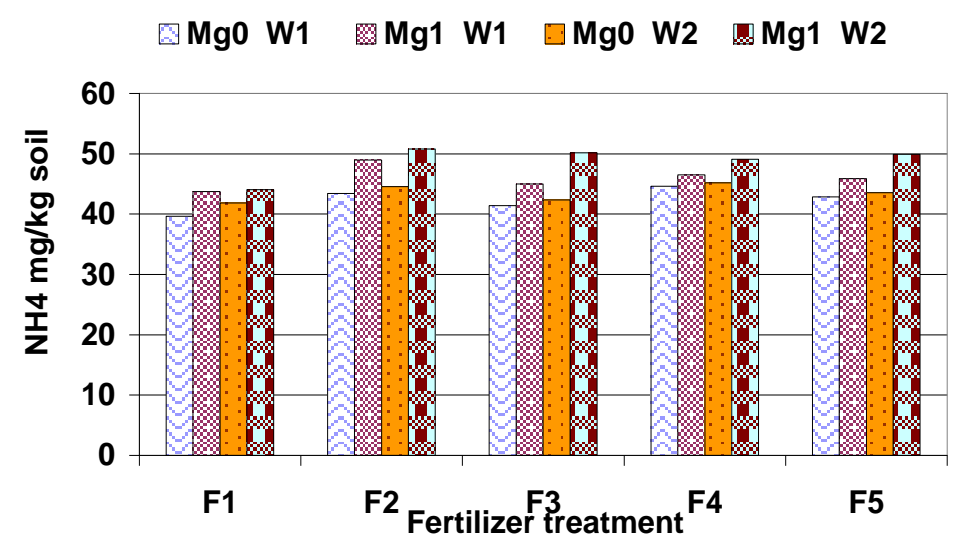

Fig (4): Effect of fertilizer treatments, $\mathbf{M g}$, and water content on $\mathrm{NH}_{4}$ in the upper $5 \mathrm{~cm}$ soil. 
Data in Fig (5) show the interaction effect of magnesium, water and fertilizer in the upper soil section $(0-5 \mathrm{~cm})$ it found that increased magnesium concentration percentage as compared to $\mathrm{F} 1$. These increases were $\mathrm{MgOW} 1$ (52.79, 89.18, 119.02 and $9.22 \%)$ and MgOW2 (34.18, 24.89, 41.35 and $12.24 \%)$. It noticed from these percentages that treatment with F4 gave the highest increasing percentage of magnesium as compared to control. Under Mg1W1 (30.74, 44.81, 28.33 and 62.04\%) and Mg1W2 (54.20, 56.12, 36.71 and $61.19 \%$ ). It noticed from these percentages that treatment with F5 gave the highest increasing percentage of magnesium as compared to control.

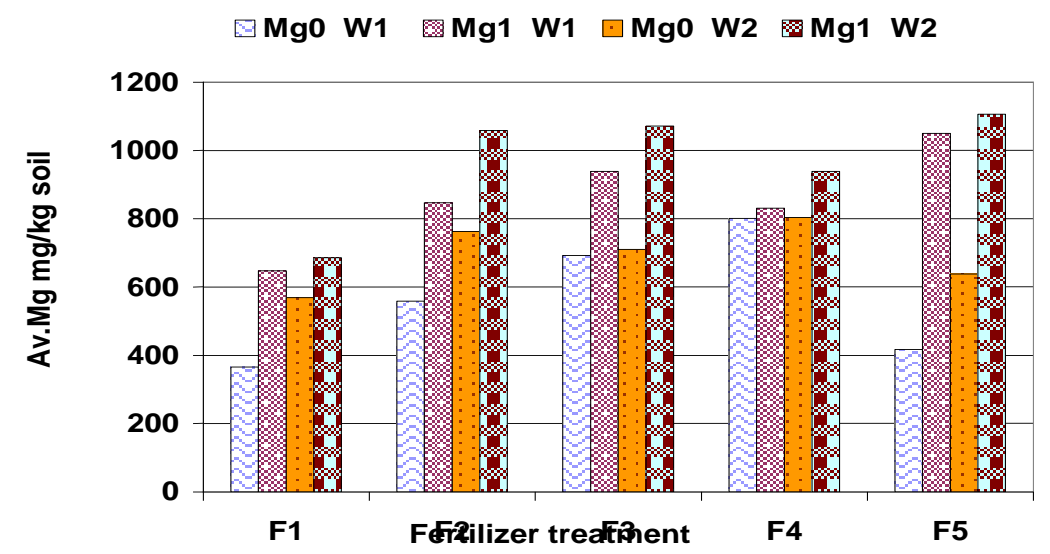

Fig (5): Effect of fertilizer treatments, $\mathrm{Mg}$, and water content on $\mathrm{Av} . \mathrm{Mg}$ in the upper $5 \mathrm{~cm}$ soil.

2. Available nutrients $\left(\mathrm{mg} \mathrm{kg}^{-1}\right)$ in the lower soil section $(5-10 \mathrm{~cm})$ :-

a. Single effect

Data listed in Table (3) illustrate that with $\mathrm{Mg}$ addition, the content of Av. Ammonium in the second section of soil column was increased but it was insignificantly, whereas the other Av. nutrients increased significantly with adding of $\mathrm{Mg}$. The increasing percentage of nutrients availability were as follow $\mathrm{Mg}>\mathrm{P}>\mathrm{NO}_{3}{ }^{-}>\mathrm{K}>\mathrm{NH}_{4}{ }^{+}$with $\mathrm{Mg}$ addition.

Concerning water content treatments, it found that all Av. nutrients increased significantly with $150 \%$ of field capacity. The increasing percentage were $11.19,23.79,2.61,6.63$ and $26.38 \%$ as compared with the control for Av. Mg, $\mathrm{K}, \mathrm{NH}_{4}{ }^{+}, \mathrm{NO}_{3}{ }^{-}$and $\mathrm{P}$ respectively

Concerning fertilizer treatments, it found that with fertilizer treatments additions the content of all Av. nutrients in the second section of soil column increased significantly. The increasing percentages of Av. magnesium were (86.79, 38.48, 20.42 and $60.11 \%)$, Av. potassium was (12.12, 32.12, 23.03 and $20 \%$ ), Av. ammonium was (13.26, 5.87, 9.77 and 10.87\%), Av. nitrate was $(36.92,31.06,29.45$ and $33 \%)$ and Av. phosphorus was $(7.13,22.99$, 56.12 and $77.12 \%)$ as compared with control. 
Hammad, S. A. et al.

Table 3: Effect of $\mathrm{Mg}$, water content and fertilizer treatments on available nutrients in the lower section of the soil column (5$10 \mathrm{~cm})$.

\begin{tabular}{|c|c|c|c|c|c|}
\hline Treatments & $\mathrm{K}$ & $\mathrm{NH}_{4}$ & $\mathrm{NO}_{3}$ & $\mathbf{P}$ & Mg \\
\hline Mg1 & $181.74 \mathrm{~b}$ & $40.01 \mathrm{a}$ & $45.14 \mathrm{~b}$ & $21.22 \mathrm{~b}$ & $597.36 \mathrm{~b}$ \\
\hline Mg2 & $196.17 \mathrm{a}$ & $42.40 \mathrm{a}$ & $50.84 \mathrm{a}$ & $25.64 \mathrm{a}$ & $729.84 \mathrm{a}$ \\
\hline F test & ** & NS. & ** & ** & ** \\
\hline LSD at $5 \%$ & 4.844 & - & 0.519 & 0.843 & 4.7695 \\
\hline W1 & $168.87 \mathrm{~b}$ & $40.67 \mathrm{~b}$ & $46.45 \mathrm{~b}$ & $20.70 \mathrm{~b}$ & $628.44 \mathrm{~b}$ \\
\hline W2 & $209.04 \mathrm{a}$ & $41.73 \mathrm{a}$ & $49.53 \mathrm{a}$ & $26.16 \mathrm{a}$ & $698.76 \mathrm{a}$ \\
\hline F test & ** & 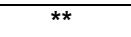 & ** & ** & ** \\
\hline LSD at $5 \%$ & 2.254 & 0.327 & 1.531 & 0.928 & 1.924 \\
\hline F1 & $160.88 \mathrm{~d}$ & $38.17 \mathrm{~d}$ & $38.06 \mathrm{~d}$ & $17.66 \mathrm{e}$ & $470.10 \mathrm{e}$ \\
\hline $\mathbf{F 2}$ & $180.38 \mathrm{c}$ & $43.23 \mathrm{a}$ & $52.11 \mathrm{a}$ & $18.92 \mathrm{~d}$ & $878.10 \mathrm{a}$ \\
\hline F3 & $212.55 \mathrm{a}$ & $40.41 \mathrm{c}$ & $49.88 \mathrm{~b} \mathrm{c}$ & $21.72 \mathrm{c}$ & $651.00 \mathrm{c}$ \\
\hline F4 & $197.93 \mathrm{~b}$ & $41.90 \mathrm{~b}$ & $49.27 \mathrm{c}$ & $27.57 \mathrm{~b}$ & $566.10 \mathrm{~d}$ \\
\hline F5 & $193.05 \mathrm{~b}$ & $42.32 \mathrm{ab}$ & $50.62 \mathrm{~b}$ & $31.28 \mathrm{a}$ & $752.70 \mathrm{~b}$ \\
\hline F test & ** & ** & $\star \star \star *$ & $\star \star *$ & ** \\
\hline LSD at $5 \%$ & 7.536 & 1.322 & 0.982 & 0.869 & 2.573 \\
\hline
\end{tabular}

b. Interaction effect:-

Data in Fig (6) show the interaction effect of magnesium, water and fertilizer in the lower soil section $(5-10 \mathrm{~cm})$ it found that increased the percentage of potassium concentration as compared to $\mathrm{F} 1$. Under Mg0W1 were $(13.16,26.32,23.68$ and $21.05 \%)$, MgOW2 were $(25.64,41.03,30.77$ and $28.21 \%)$, Mg1W1 were (10.81,24.32,24.32 and 10.81\%) and Mg1W2 were $(1.96,35.29,15.69$ and $19.61 \%)$. It noticed from these percentages that treatment with F3 gave the highest increasing percentage of potassium as compared to control.

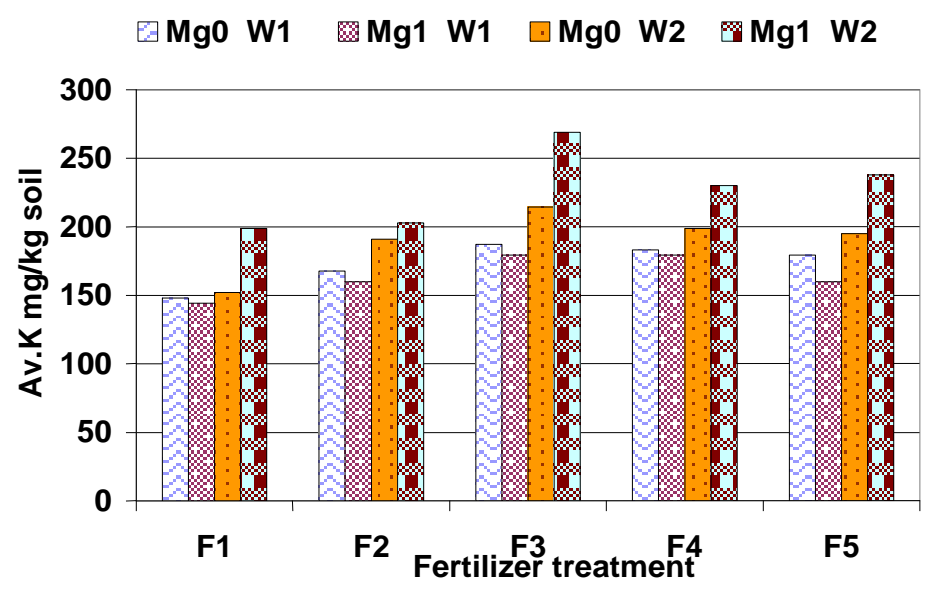

Fig (6): Effect of fertilizer treatments, Mg, and water content on Av. K in the lower $5-10 \mathrm{~cm}$ soil. 
Data in Fig (7) show the interaction effect of magnesium, water and fertilizer in the lower soil section $(5-10 \mathrm{~cm})$ it found that increased phosphorus concentration percentage as compared to $\mathrm{F} 1$. These increases were $\mathrm{MgOW} 1$ $(0.75,17.51,36.13$ and $46.56 \%)$ and MgOW2 (6.33, 20.39, 75.23 and 89.65\%), Mg1W1 (7.71, 19.09, 70.47 and 86.25\%) and Mg1W2 (12.01, $31.93,45.30$ and $78.59 \%)$. It noticed from these percentages that treatment with F5 gave the highest increasing percentage of phosphorus compared to control.

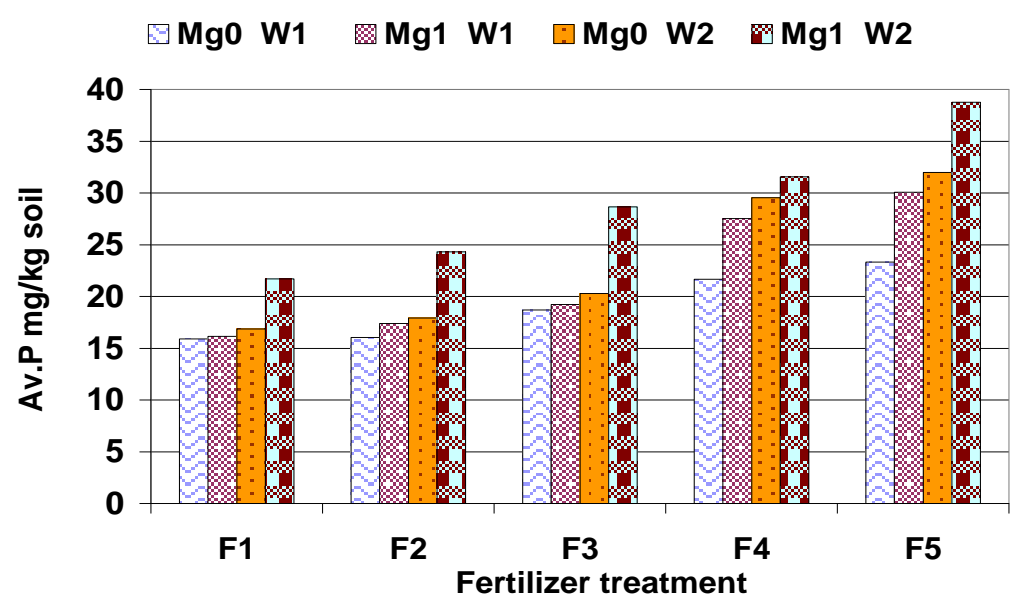

Fig (7): Effect of fertilizer treatments, $\mathrm{Mg}$, and water content on Av. P in the lower $5-10 \mathrm{~cm}$ soil.

Data in Fig (8) show the interaction effect of magnesium, water and fertilizer in the lower soil section $(5-10 \mathrm{~cm})$ it found that increased nitrate concentration percentage as compared to $\mathrm{F} 1$. These increases were $\mathrm{MgOW} 1$ (48.35, 34.40,35 and 37.69\%), Mg0W2 (43.05, 35.94, 35.96 and $42.71 \%)$ and Mg1W2 (28.86, 22.71, 20.22 and 21.13\%). it noticed from these percentages that treatment with $\mathrm{F} 2$ gave the highest increasing percentage of nitrate as compared to control. Under Mg1W1 (27.35, 29.88, and $26.04 \%$ ). it noticed from these percentages that treatment with F3 gave the highest increasing percentage of nitrate as compared to control. 
Hammad, S. A. et al.

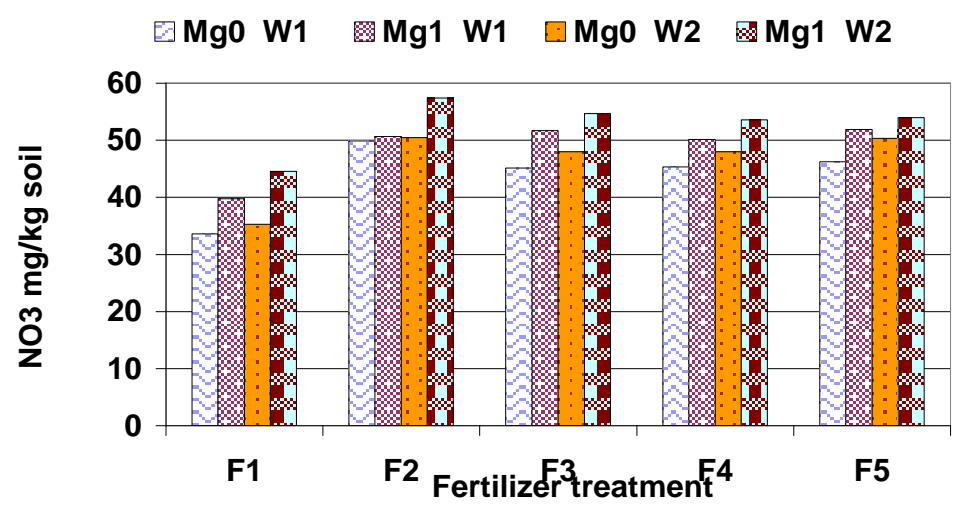

Fig (8): Effect of fertilizer treatments, $\mathrm{Mg}$, and water content on $\mathrm{NO}_{3}$ in the lower $5-10 \mathrm{~cm}$ soil.

Data in Fig (9) show the interaction effect of magnesium, water and fertilizer in the lower soil section $(5-10 \mathrm{~cm})$ it found that increased the percentage of ammonium concentration as compared to F1. These increases were MgOW1 (14.92, 7.14, 12.84 and 11.63\%), MgOW2 (13.10, 6.88, 10.92 and 10.27\%), Mg1W1 (13.57, 4.89, 9.25 and 10.29\%) and Mg1W2 (11.63, $4.79,6.48$ and $11.37 \%$ ). It noticed from these percentages that treatment with F2 gave the highest increasing percentage of ammonium as compared to control.

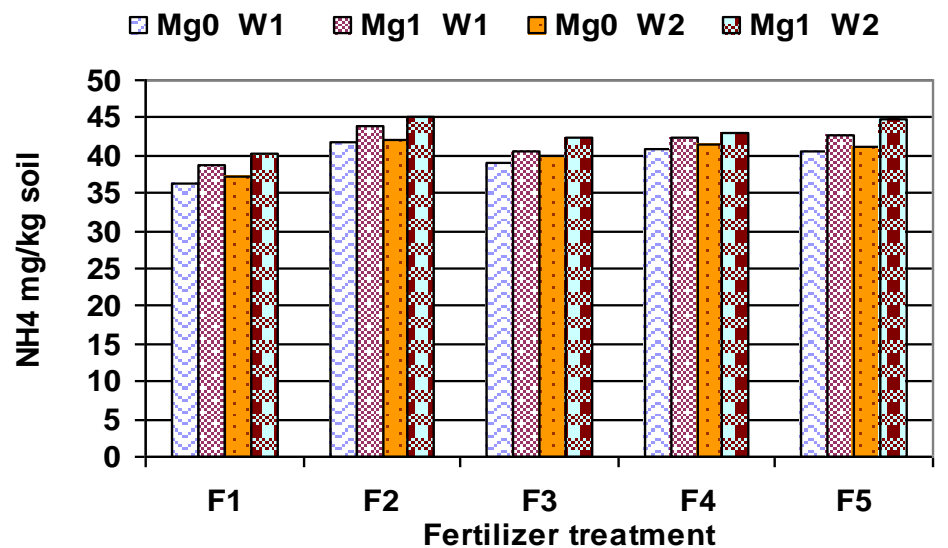

Fig (9): Effect of fertilizer treatments, $\mathrm{Mg}$, and water content on $\mathrm{NH}_{4}$ in the lower $5-10 \mathrm{~cm}$ soil. 
Data in Fig (10) show the interaction effect of magnesium, water and fertilizer in the lower soil section $(5-10 \mathrm{~cm})$ it found that increased the percentage of magnesium concentration as compared to F1. These increases were MgOW1 (102.25,43.09,37.30 and $64.63 \%)$, Mg1W1 (86.06,44.50,20.78 and 60.88\%), MgOW2 (77.69,16.79,15.04 and 55.64\%) and Mg1W2were $(84.82,49.11,13.17$ and $60.27 \%)$. It noticed from these percentages that treatment with F2 gave the highest increasing percentage of magnesium as compared to control.

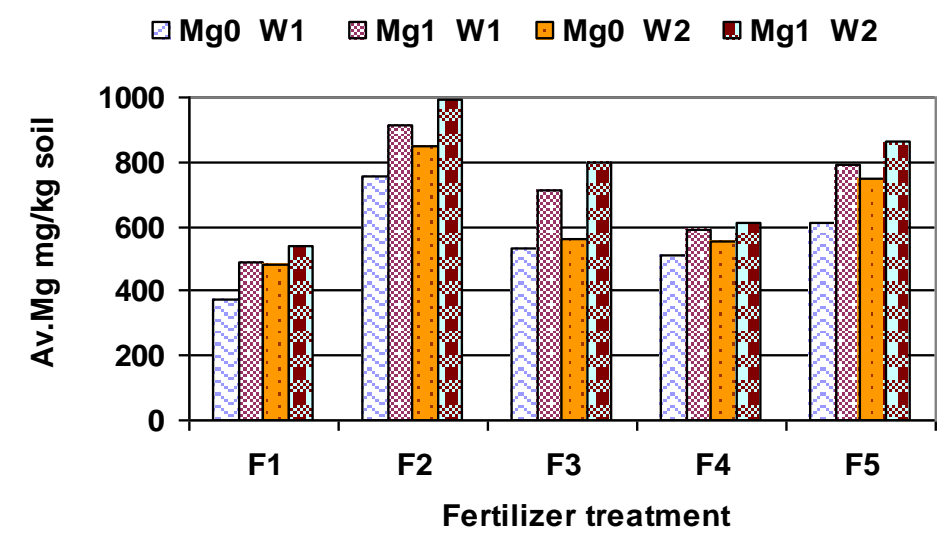

Fig (10): Effect of fertilizer treatments, $\mathrm{Mg}$, and water content on Av. Mg in the lower $5-10 \mathrm{~cm}$ soil.

Data reveal that the content of all Av. nutrients increased with adding Mg, as mentioned by Fuad, et al., (1972), Moustafa and Omran (2006) and Rasul, et al., (2011). It reveals that the content of all Av. nutrients increased with $150 \%$ field capacity. As obtained by Zeng and Brown (2000) and Dontsova, et al., (2005). In addition, Data reveal that treatment F3 gave the highest increasing percentage of potassium compared to control. As recorded by Jeganathan (1990) and Assimakopoulos, et al., (1994).

Data reveal that treatment F5 gave the highest increasing percentage of phosphorus compared to control. As mentioned by Fageria (1983) and Lasa, et al., (2000). It is also reveal that treatment F4 and F5 gave the highest increasing percentage of magnesium compared to control in the upper 0-5 cm soil. As recorded by Bell and Robson (1999).

Data reveal that treatment F2 gave the highest increasing percentage of magnesium compared to control in the lower $5-10 \mathrm{~cm}$ soil. As obtained by Moustafa and Omran (2006) and Jayaganesh et al., (2011).

It can be concluded that the highest mean values of the content of all Av. nutrients obtained from Mg1W2 among all treatment. 


\section{REFERENCES}

Assimakopoulos, J. H., Yassoglou, N. J., and Bovis, C. P. (1994). Effects of incubation at different water contents, air-drying and K-additions on potassium availability of a vertisol sample. Geoderma, 61:223-236.

Badiane, O., M. Bader, M. R. El-Amir, A. El-Miniawy, F. Goletti and J. Soil. (1994). Agricultural input and output market in Egypt: Initial impact and future policy issues. Paper II. 3. A Report Submitted to the MALR, Egypt and Int. Food Policy Res. Inst. /Washington, D. C.

Bell, S., and Robson A., (1999). Effect of Nitrogen Fertilization and Growth, Canopy Density, and Yield of Vitis vinifera CV Cabernet sauvignon. Amer.J.Enol.Vitic, 50(3):351-358.

Dewis, J., and F. Freites (1970). Physical and chemical methods of soil and water analysis. Soil Bultin 10, Fao, Rome.

Dontsova, K.M., L.D. Norton, C.T. Johnston, and J.M. Bigham. (2004). Influence of exchangeable cations on water adsorption by soil clays. Soil Sci. Soc. Am. J. 68:1218-1227

Dontsova, K.M., L.D. Norton, and C.T. Johnston (2005). Calcium and Magnesium Effects on Ammonia Adsorption by Soil Clays. Soil Sci. Soc. Am. J. 69:1225-1232.

El-Fouly, M. M., Rezk, A. I., Nofal, O. A., and Abou El-Nour, E. A. A., (2010). Depletion of magnesium in Egyptian soils, its content in crops and estimated needs African Journal of Agricultural Research, Vol. 5(10), 1060-1067.

Fageria, N. K., (1983). lonic interactions in rice plants from dilute solutions. Plant and Soil, 70, 309-316.

Fuad, H. H. and Babcock, K. L., (1972). Further studies on cation uptake from Bentonits suspensions by excised barley roots. Plant and Soil 36:681692. Cited from El-Ashtar, A.F.A.M., (1976).

Gomez, K. A., and A. A. Gomez (1984). Statistically procedures for Agricultural Research. 2nd Ed. John Wiely and Sons, pp.680.

Hesse, P. R. (1971). A textbook of soil chemical analysis. Jonn Murry (Publishers) Ltd., 50 Albemarle street London.

Jayaganesh, S., Venkatesan, S., Senthurpandian, V. K., and Poobathiraj, K., (2011). Vertical distribution of magnesium in the Laterite soils of South India. Int. J. Soil. Sci, 1-6

Jeganathan, M., (1990). Studies on potassium-magnesium interaction in coconut (Cocos nucifera). Plant and Soil, 124:265-271.

Lasa, B., Frechilla, S., Aleu, M., Gonz'alez-Moro, B., Lamsfus, C., and P.M. Aparicio-Tejo (2000). Effects of low and high levels of magnesium on the response of sunflower plants grown with ammonium and nitrate. Plant and Soil, 225: 167-174.

Moustafa. Zeinab. R., and Samya, E. H. Omran, (2006). Effect of foliar spray with boron or magnesium in combination with nitrogen fertilization on sugar beet plants. Egypt. J. Soil. Sci. 46(2), 115-129.

Piper, C. S. (1950). Soil and plant analysis. Inter. Science publishers Inc., New yore. 
Rasul, G. A. M., A. O. Esmail and R. J. Mekha (2011). The role of magnesium in increasing of phosphorus fertilizer efficiency and wheat yield. Mesopotamia J. of Agric. 39 (2).

Senthurpandian, V.K., S. Venkatesan, S. Jayaganesh. (2009). Calcium and magnesium releasing capacity of Alfisols under tea in south India. Geoderma 152. 239-242

Zeng, Q., and Brown, P. H., (2000). Soil potassium mobility and uptake by corn under differential soil moisture regimes. Plant and Soil, 221: 121134.

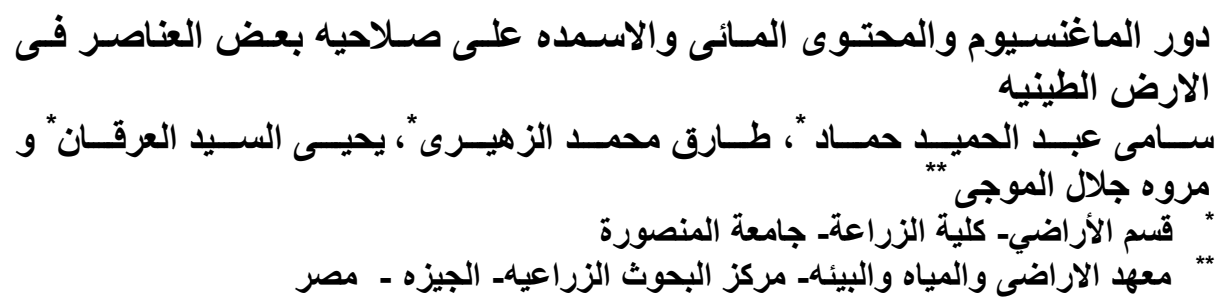

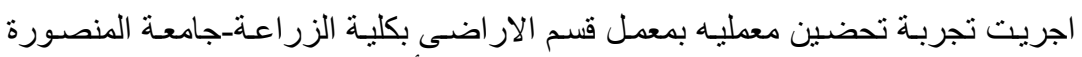

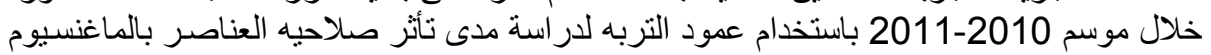

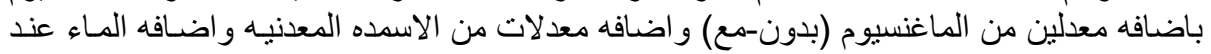

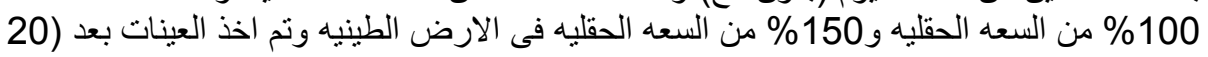

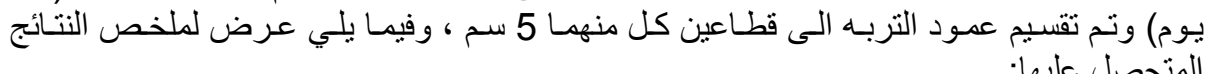

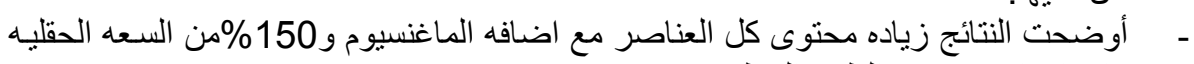

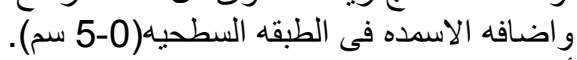

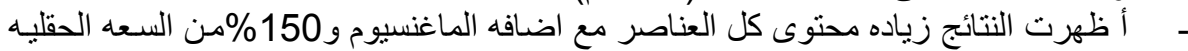

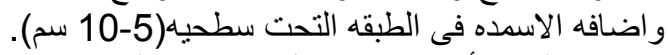

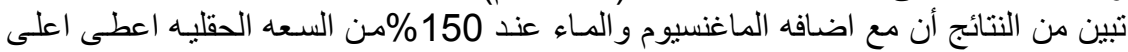

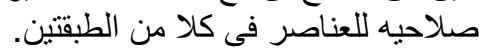

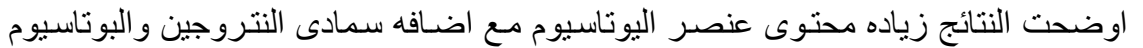

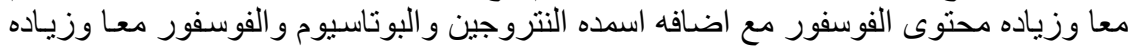
محتوى النتروجين مع اضئافه الأسمده النتروجينيه وذللك في كلا الطبقينتين.

كلية الزراعه- جامعه المنصورة كلية الزراعه- جامعه الزعاعه المنازيق

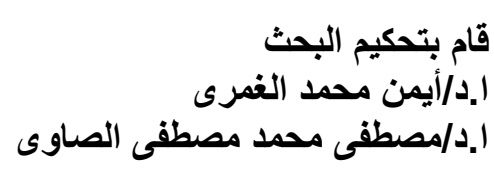

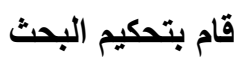

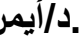

ا.د/مصطقى محمد مصطفى الصاوى إين 